\title{
Flood vulnerability mapping using the spatial multi-criteria evaluation (SMCE) method in the Minraleng Watershed, Maros Regency, South Sulawesi
}

\author{
Muhammad Fadhil ${ }^{1}$, Yoanna Ristya ${ }^{2}$, Nahra Oktaviani $^{2}$, and Eko Kusratmoko ${ }^{2 *}$ \\ ${ }^{1,2}$ Department of Geography, Faculty of Mathematics and Natural Science, Universitas Indonesia, \\ Depok 1624
}

\begin{abstract}
This study focuses on the assessment of flood-vulnerable areas in the Minraleng watershed, Maros Regency, where the area experiences floods every year. Spatial analysis in the Geographic Information System (GIS) environment has been applied to estimate flood-vulnerable zones using six relevant physical factors, such as rainfall intensity, slope, Elevation, distance from the rivers, land use and soil type. The relative importance of physical factors has been compared in paired matrices to obtain weight values using the Spatial Multi-Criteria Evaluation (SMCE) method. The result showed that the areas located in Camba sub-district had the high vulnerability. The region with a high and very high vulnerability to flood were spread with an area of 436 ha $(0,84 \%)$ and 6.168 ha $(11.8 \%)$.
\end{abstract}

\section{Introduction}

Flood is the number one hydrometeorological disaster in Indonesia, in the last ten years floods have become the most disasters in Indonesia. During 2018, the National Disaster Management Agency recorded 679 flood events, out of a total of 2572 disaster events. In South Sulawesi Province there were 24 recorded flood events [1]. The worst floods in South Sulawesi occurred in 2019 where based on BNPB data, floods, landslides and tornadoes were spread across 13 districts / cities. From BNPB calculations, 78 people died, 7 people were reported missing, 47 people were injured, and 9,429 people were displaced. [2].

Flood-related problems and many applications have been proven to be solved through detailed planning studies and projects in floodplain areas [3]. Determining flood-vulnerable areas is very important for decision makers for planning and managing activities. Determination of flood-vulnerable areas can be done by mapping. Flood vulnerability map is a tool for flood vulnerability assessment that is used to understand the level of vulnerability that is harmed. To identify the level of vulnerability, flood vulnerability maps

\footnotetext{
* Corresponding author: eko.kusratmoko@sci.ui.ac.id
} 
are built based on physical and ecological systems in the environment using Geographic Information Systems (GIS) [4].

There are several methods for making flood vulnerability maps, for example, the Spatial Multi-Criteria Evaluation (SMCE) method that weighs various variabels logically, has been applied in several studies because $80 \%$ of the data used by decision makers is geographically related using the application of Geographic Information Systems (GIS). GIS provides more and better information for decision-making situations [3]. Furthermore, the Analytical Hierarchy Process (AHP) method allows a qualitative and quantitative approach to solve complex decision problems. AHP helps determine the numerical weights that represent the relative importance of various factors used for flood vulnerability models [5, 6]. This study uses the SMCE method because this method is a type of supporting method that combines GIS and AHP to identify and rank various variabels that indicate floodvulnerable areas [7].

Even though the Minraleng watershed is a flood-vulnerable area, research on disasters, especially flooding in the region, is very lacking, encouraging researchers to conduct research in the Minraleng watershed with the aim of research to map flood-vulnerable areas and identify mitigation efforts in the Minraleng watershed, Regency Maros The mapping of Flood Vulnerable Areas in the Minraleng watershed, Maros Regency is expected to be used to build an early warning system, as a basis for disaster mitigation, decision-making tools in designing land use and infrastructure, as well as reducing the risk of flood disasters in the Minraleng watershed area [11].

\section{Data and Methods}

\subsection{Study Area}

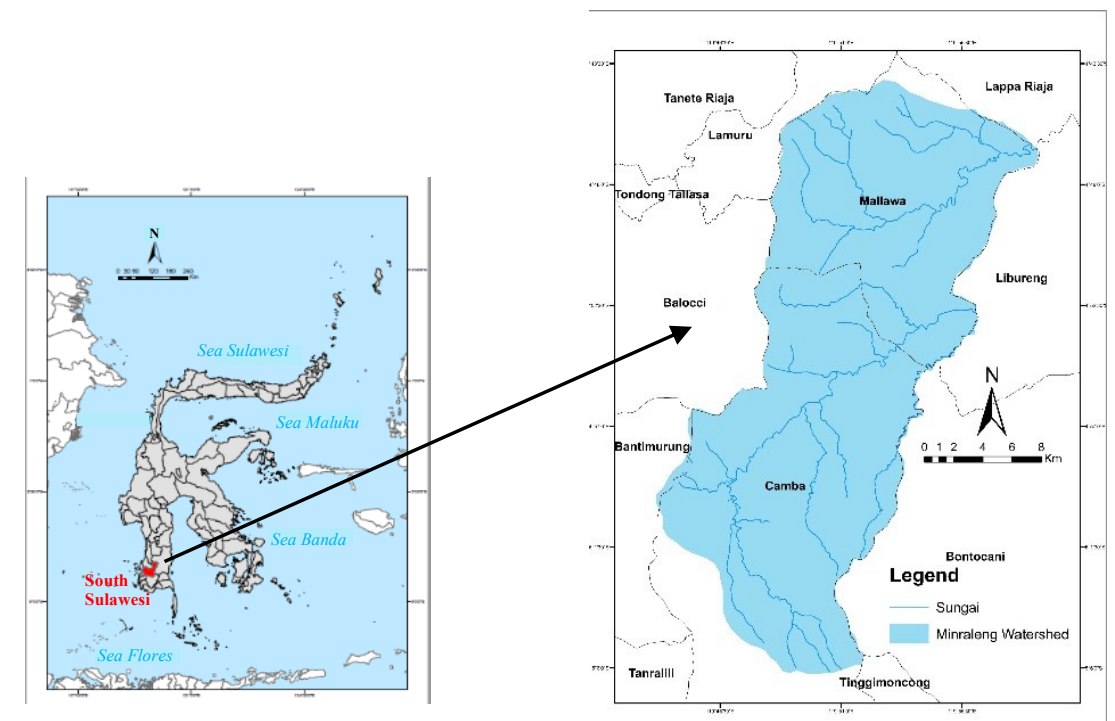

Fig. 1. Study Area

This research area is located in one of the Walanae watersheds, the Minraleng watershed. Walanae watershed is included in the category of priority I (one) watershed which is often flooded. Walanae watershed has an area of around $72 \mathrm{Ha}$. Geographically it is located in the position of $3^{\circ} 59$ ' 03 "- $5^{\circ} 8$ ' $45^{\prime}$ LS and '09 "' 03" BT [9]. 
The Minraleng upstream watershed is an upstream Walnae watershed located in Maros Regency and is located in three districts including Cenrana District, Camba District, and Mallawa District. Minraleng watershed land area of 52.336 .51 ha, including 18.446 ha is a critical area, so that this watershed is a priority area for watershed management. One of the problems in the Upper Minraleng Watershed, is land cover with a variety of land use patterns that are not good, so that the impact on flooding in the rainy season and drought in the dry season in downstream villages [10].

\subsection{Data}

To reach the level of vulnerability, flood vulnerability maps was built based on physical factors platform environment. The physical factors used in GIS need to be agreed with a procedure called multi-criteria analysis that weighs variabels logically [4]. According to [3], the choice of criteria that have spatial references is an important and in-depth step in multi-criteria decision analysis. Therefore, the decisive criteria in this study were chosen because of their significance in causing flooding in the study area. The factors consist of six variabels, namely: Slope (S), Elevation (A), Distance from the Rivers (DR), Land Use (LU), Rainfall Intensity (R), and Soil Type (ST). These variabels have been manipulated in GIS with new classes categorized into three levels of vulnerability namely low, moderate, high flood vulnerable.

Data collected in this research are primary data and secondary data. Primary data used in this study include the results of interviews with people who live in flood-vulnerable areas and local governments that treat floods, namely BPBD Maros Regency. We collected data of digital elevation model (DEM) of the research area from USGS with 30-m pixel size to generate slope and Elevation. Distance from rivers was calculated using the river data from Geospatial Information Agency of Indonesia. The soil types were acquired from a 100.000scale soil map from Agricultural Research and Development Agency of Maros Regency. In this research, land use were derived from National Land Agency of Indonesia 2018. The precipitation data was prepared using the last 28 years (1982-2010) of historical rainfall data. Also, the Spline method using Arc GIS 10.1 was used for spatial interpolation.

\subsection{Methods}

In determining flood-vulnerable areas in the study area, two stages were carried out. First is to determine the factors that cause flooding in the study area and second, to apply the Multi-Criteria Evaluation technique in finding flood-vulnerable areas based on factors related to flooding in the study area. In evaluating flood-vulnerable areas, the Pair-wise Comparison Comparison Method is used which is an integral part of the Analytical Hierarchy Process (AHP) proposed by Saaty in 1980 [3].

In this study, the principles of Multi-Criteria Decision Making (MCDM) in the context of the Analytic Hierarchy Process (AHP) have been integrated into GIS to simulate and estimate flood-vulnerable zones [5]. The physical factors used in GIS need to be linked to a procedure called multi-criteria analysis (MCA) that weighs variabels logically [4]. Because it is an integration of GIS and AHP, this method is called Spatial Multi-Criteria Evaluation. The results of the final analysis are expected to successfully show the flood area in the study area. By using AHP, it can obtain the relative significance of the relevant factors after the paired comparison matrix is built. The weight of each variabel area is determined after they are ranked according to their relative importance.

Table 1. Variabels of Flood Vulnerability

$\mathrm{S}$

DR

LU

E
ST 


\begin{tabular}{|c|c|c|c|c|c|c|}
\hline $\mathrm{R}$ & 1 & 3 & 3 & 7 & 5 & 5 \\
\hline $\mathrm{S}$ & $1 / 3$ & 1 & $1 / 3$ & 3 & 3 & 3 \\
\hline $\mathrm{DR}$ & $1 / 3$ & 3 & 1 & 7 & 3 & 5 \\
\hline $\mathrm{LU}$ & $1 / 7$ & $1 / 3$ & $1 / 7$ & 1 & $1 / 3$ & $1 / 3$ \\
\hline $\mathrm{E}$ & $1 / 5$ & $1 / 3$ & $1 / 3$ & 3 & 1 & 3 \\
\hline $\mathrm{ST}$ & $1 / 5$ & $1 / 3$ & $1 / 5$ & 3 & $1 / 3$ & 1 \\
\hline
\end{tabular}

Source: (Seejata, 2018)

The value of each row is compared with each column to determine the relative importance to get the rating score. For example, rainfall intensity is significantly more important than land use and is therefore rated 7.

Table 2. Normalization of flood vulnerability variables

\begin{tabular}{|c|c|c|c|c|c|c|c|c|}
\hline Variabels & Rainfall & Slope & $\begin{array}{c}\text { Distance } \\
\text { from } \\
\text { Rivers }\end{array}$ & $\begin{array}{c}\text { Land } \\
\text { Use }\end{array}$ & Elevation & $\begin{array}{c}\text { Soil } \\
\text { Type }\end{array}$ & Average & Wi \\
\hline Rainfall & 0,45 & 0,38 & 0,60 & 0,29 & 0,39 & 0,29 & 0,40 & 4 \\
\hline Slope & 0,15 & 0,13 & 0,07 & 0,13 & 0,24 & 0,17 & 0,15 & 1,5 \\
\hline $\begin{array}{c}\text { Distance } \\
\text { from Rivers }\end{array}$ & 0,15 & 0,38 & 0,20 & 0,29 & 0,24 & 0,29 & 0,25 & 2,5 \\
\hline Land Use & 0,06 & 0,04 & 0,03 & 0,04 & 0,03 & 0,02 & 0,04 & 0,4 \\
\hline Elevation & 0,09 & 0,04 & 0,07 & 0,13 & 0,08 & 0,17 & 0,10 & 1 \\
\hline Soil Type & 0,09 & 0,04 & 0,04 & 0,13 & 0,03 & 0,06 & 0,06 & 0,6 \\
\hline
\end{tabular}

Source: (Seejata, 2018)

In this study, flood vulnerability with very low classes has score 2 , low classes has score 4 , modeate classes has score 6 , high classes has score 8 , and very high classes has score 10.

\subsection{Validation and Accuracy of Physical to Flood Vulnerability Map}

Flood vulnerable maps can be easily verified using flood event inventory data. For this study, the location of the flood event was collected from old unpublished reports, newspapers and physical field visits where interviews with residents were conducted [13]. In this study, for the purpose of validation using Area Under Curve (AUC), where the efficiency and performance of the SMCE model is assessed. AUC is calculated based on the cumulative area under different flood vulnerable on one side and the cumulative number of flood events in different vulnerable areas on the other side.

$$
R=\frac{n i}{N i} \sum\left(\frac{n i}{N i}\right) \times 100 \%
$$

Where this is the number of flood in category $\mathrm{i}$ and $\mathrm{Ni}$ the number of pixels in category I.

\section{Result}

\subsection{Flood Vulnerability Mapping}

After processing the data for each variabel, a classification of each variabel produce a flood vulnerable map. The maps made are categorized into five levels of vulnerability classes namely very low, low, moderate, high and very high flood zones. The results show that the very high flood area covers $0.84 \%$ (436 ha) of the total area, high vulnerability rate of $11.8 \%$ (6.168 ha), moderate vulnerability level of $45 \%$ (23.532 ha), and the level of vulnerability is low and very low 36\% (18.965 ha) and 6\% (3233 ha). 

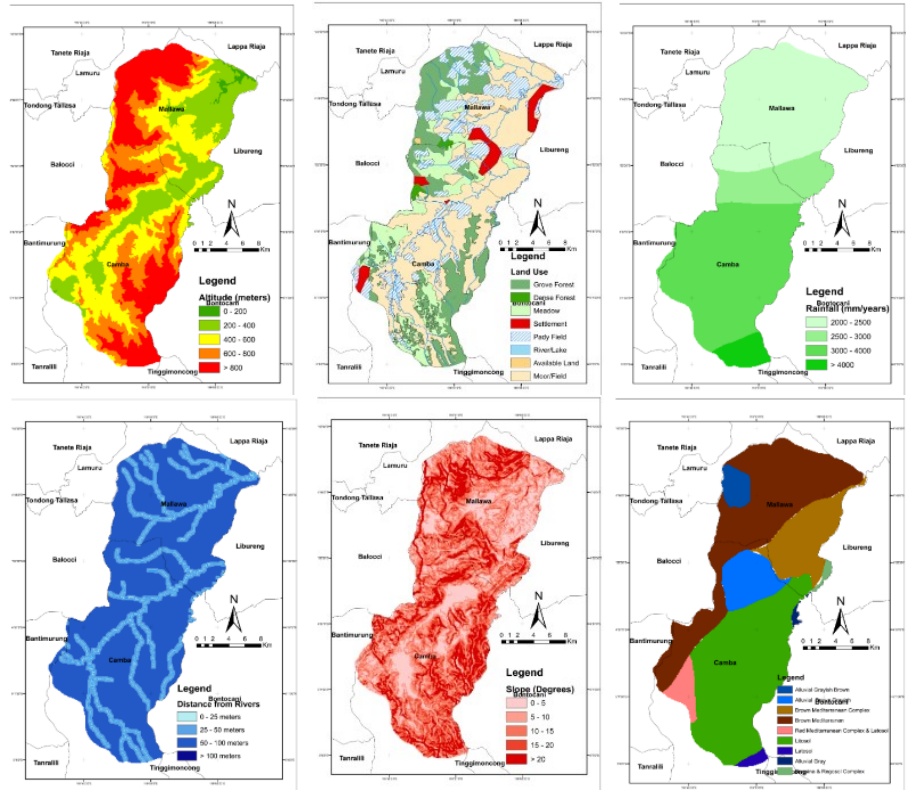

Fig. 2. Spatial Data variabels, a) Elevation, b) Land use, c) Rainfall, d) Distance from the river, e) Slope, f) Soil type

In the areas with high levels of vulnerability are very low areas with low Elevation and slope. In addition, the existence of the main river is also the biggest contributor to water from flooding which is directly proportional to the intensity of rainfall. The dominant use of agricultural land in the Minraleng watershed is also a factor vulnerable to flooding in the region. Although, flooded areas often appear near river banks from floodplain areas. However, in Camba District, Maros Regency, flood areas were found due to high elevation and high slope. Based on information from Camba District in February 2019 floods occurred in 6 villages out of a total of 8 villages, only Benteng Village and Pattanyamang Village were not affected by flooding.

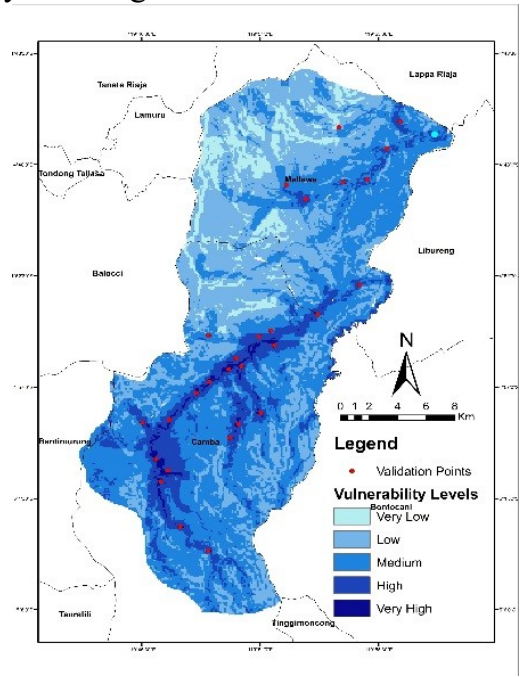

Fig 3. Flood vulnerability map in Minraleng watershed, Maros Regency. 
Based on information from the Camba District secretariat the floods that hit this region had a height of up to three meters to evacuate victims trapped at home using rubber boats. Floods in this area have blocked access roads, collapsed reservoirs, damaged agricultural communities, destroyed several houses near the river. Data on flood inventory inventories in early 2019 can be seen in (Fig. 5) Camba District.

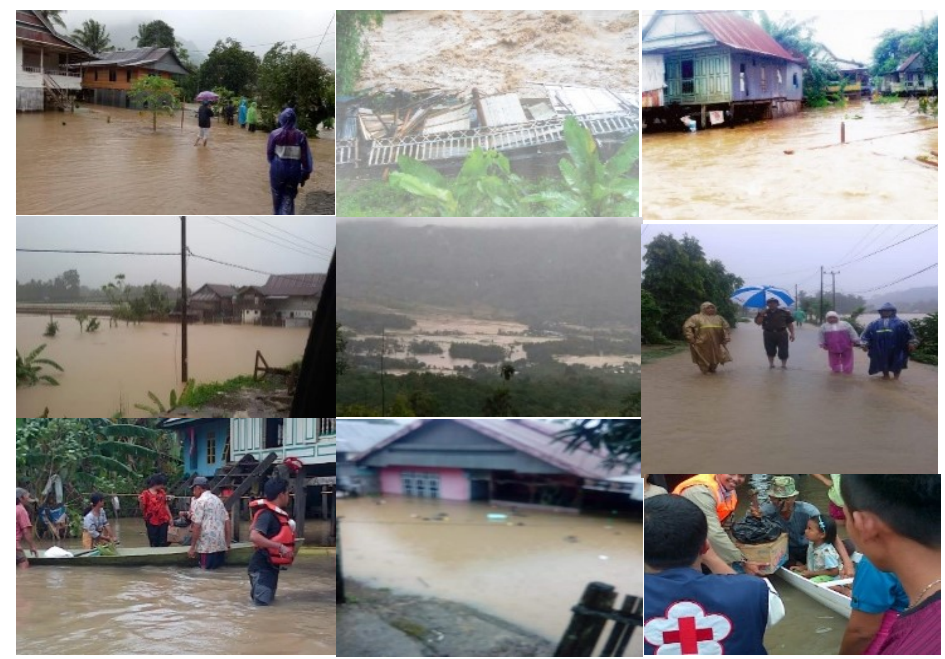

Fig 4. Data on Inventory of Flood Disasters in Camba District.

Source : BPBD, Maros Regency

\subsection{Validation Results of Flood Vulnerability Mapping}

Based on the results of the field survey and data collection on flood events in the Minraleng watershed, 30 flood events are located at various levels of vulnerability, from 30 flood events, 25 are located in the high hazard class and very high, while 5 other events are located under high class and very high. From the results of the calculation of ROC using the SPSS 20 application obtained an accuracy of $94.4 \%$ with a confidence interval of $95 \%$.

\subsection{Flood Mitigation Efforts}

Based on interviews with BPBD staff in Maros Regency, it is known that several mitigation efforts have been carried out to deal with flood disasters, including by making disaster risk assessment maps and making disaster risk assessments. Mitigation efforts in one of the villages in Camba Sub-district, Pattiro Deceng Village, are known to some mitigation efforts that have been carried out based on information from the Village Head, by dredging river sediments to accommodate more water, building reservoirs to regulate water discharge, and building embankment by the river. However, in reality this has not been able to prevent the occurrence of floods due to high rainfall intensity, especially in Pattiro Deceng Village.

\section{Conclusions}

Based on the research results, most of the Minraleng watershed areas are flood-vulnerable areas, especially in the southern part of the Camba District and Cenrana District. Areas with 
moderate vulnerability are the most extensive areas based on flood hazard maps that have been made with a percentage of $45 \%$ of the total area and area of 23.532 ha, while for high and very high levels of vulnerability have a percentage and area of $0.84 \%$ (436 ha) and $11.8 \%(6,168 \mathrm{ha})$. The level of prediction an accuracy rate using AUC of 94.4\%. Some flood mitigation efforts have been carried out including by conducting disaster risk studies, installing signs in disaster vulnerable areas, dredging sediment, building reservoirs, and building embankments on river banks.

The author would like to thank the University of Indonesia through International Publication Grants Indexed 9 (PIT 9) Number: NKB-0025/UN2.R3.1/HKP.05.00/2019 that has facilitated these activities, also thank to BPBD Maros Regency who helped in the efforts to obtain data we need during this research.

\section{References}

1. DIBI, Tren Kejadian Bencana 10 Tahun Terakhir (DIBI BNPB, 2019)

2. M. Taufiqqurahman (2019). 78 Meninggal, Banjir Sulsel Paling Parah dalam 6 Tahun Terakhir, URL: news.detik.com

3. L. Dano, M. Abdul, H. Ahmad, Y. Khamaruzaman, International Conference on Future Environment and Energy IPCBEE 28, (2012)

4. S. Kamonchat, Y. Aphittha, W. Tubtim, M. Nattapon, T, Sarintip, Procedia Engineering 212, 340-347 (2018)

5. A N. Matori, IOP Conf. Series: Earth and Environmental Science (2014)

6. S. N. Azizah, Sistem Pendukung Keputusan Prediksi Tingkat Kerawanan Banjir dengan Metode Simple Moving Average dan Analytical Hierrarchy Proccess (Studi Kasus: Kota Malang (Undergraduate Thesis, Fakultas Sains dan Teknologi: Universitas Islam Negeri Maulana Malik Ibrahim, 2016).

7. C. Mohanty. S.C. Behera, J. Indian Soc. Remote Sens. 38, 345-354 (2010)

8. H. Shahabi, M. Hashim, Scientific Reports (Nature Publisher Group) 5, (2015)

9. Y. Asmoro, Daerah Aliran Sungai (DAS) Walanae, Sulawesi Selatan (Blog Universitas Indonesia, 2010).

10. M. Daasir, Jurnal Perennial 3(2), 67-75 (2007)

11. Disaster, Disaster Geografi UGM (2017).

12. A. Zerger, Environmental Modelling \& Software 17(3), 287-294 (2002).

13. S. Das, Remote Sens. Appl. Soc. Environ. 14, 60-74 (2019) 